\title{
Differences of Serum NT-PROBNP Concentration and Echocardiographic parameters predict extent and severity of coronary artery disease in patients with Acute Coronary Syndrome
}

\author{
Wafa M. Merza, phD ${ }^{1}$, zainab A. Aldhaher, MSC $^{1}$, Rasha M. Shakir, MSC ${ }^{1}$ \\ ${ }^{I}$ Department of basic sciences, Dentistry College, Baghdad University, Baghdad, Iraq.
}

\begin{abstract}
Introduction: Plaque disruption exposes thrombogenic substances that may produce an extensive thrombus in the infarct-related artery. The precursor of BNP and N-terminal pro - Brain Natriuretic Peptide (NT-proBNP) is a pre-pro hormone BNP. The prohormone is released during homodynamic stress from the left and right cardiac ventricle in response to ventricular volume expansion and pressure overload. Recent data suggest that left ventricular end diastolic wall stress and wall stiffness may be the predominate triggers of BNP release.

Objective: To determine the level of serum NT-PRO brain natriuretic peptide which marked an increased incidence of cardiovascular events in unselected community-based individuals with many types of acute coronary syndrome admitted to cardiology care unite within 24 hour.

Patients and Methods: This prospective study was composed of 70 consecutive patients with ACS who were seen between April 2015 to April 2017, and 20 healthy subjects as control group. The present study was conducted at the Department of Bio Chemistry, College of Medicine, University of Baghdad and Baghdad Teaching Hospital. Routine blood samples were collected at admission with fasting status, and the troponin I, $C$-reactive protien, and BNP levels were measured, a specific kit for the ELIZA Centaur analyzer was used. Glucose level was measured by using enzymatic colorimetric method. the patients were divided into five groups according to type of ACS: Extensive MI, Anteroseptal MI, Anterior MI, Inferior MI, and Unstable angina. Electrocardiography and Echocardiography were performed upon hospital admission for each patient.

Results: This study included 70 patients with mean $\pm S D$ of age was $(58.77 \pm 11.45)$ years ranged from $(25-84)$ years divided into two groups: Male group included 52(74.3\%) patients, and female group included 18 (25.7\%) patients. The patients with ACS were found to have significantly higher mean ( \pm SEM) value of serum NT$P R O B N P$ concentrations $(p=0.0144)$ as compared with mean $( \pm S E M)$ value of serum control group, There was significant difference in mean $( \pm S E M)$ value of NT-PROBNP concentrations among the five patients groups, $(P$-value $=0.0255)$. The patients with ACS were found to have significantly higher mean $( \pm$ SEM) value of serum hs-CRP concentrations $(p=0.002)$ as compared with mean $( \pm S E M)$ value of serum control group. There was significant difference in mean $( \pm S E M)$ value of hs-CRP concentrations among the five patients groups, $(P$ value $=0.0478$ ). The mean $( \pm S E M)$ value of serum hs-troponin I concentrations did not differ significantly $(p=0.372)$ as compared with mean $( \pm S E M)$ value of serum control group. There was non significant difference in mean $( \pm S E M)$ value of serum hs-troponin I concentrations among the five patients groups, $(P$-value $=0.146)$.

Conclusions: Analysis of NT-proBNP help emergency physicians in managing patients with a variety of conditions. They are primarily helpful in difficult-to-diagnose causes of dyspnea. They are a strong tool in the $E D$ to differentiate ACS from its various mimics and are also helpful in monitoring of ACS therapy.
\end{abstract}

Keywords: B-type natriuretic peptide, Echocardiographic, ACS.

\section{Introduction}

Plaque disruption exposes thrombogenic substances that may produce an extensive thrombus in the infarct-related artery. Characteristically, completely occlusive thrombi lead to transmural injury of the ventricular wall in the myocardial bed subtended by the affected coronary artery and typically produce STsegment elevation on the ECG. Infarction alters the sequence of depolarization, ultimately reflected as changes in the QRS. ${ }^{1}$

Prognostic considerations must take into account other important factors, such as whether the electrocardiographic abnormality is caused by a first infarct versus subsequent infarct, the location of infarction (anterior versus inferior infarct size, and demographic factors such as patient age. ${ }^{2}$

On grossthickness of the ventricular wall, and subendocardial (nontransmural) infarcts, in which the necrosis involves the subendocardium, the intramural myocardium, or both without extending all the way through the ventricular wall to the epicardium. An occlusive coronary thrombosis appears to be far more common when the infarction is transmural and localized to the distribution of a single coronary artery.

DOI: $10.9790 / 3008-1203053742 \quad$ www.iosrjournals.org $37 \mid$ Page


Nontransmural infarctions, however, frequently occur in the presence of severely narrowed but still patent coronary arteries. Gross alterations of the myocardium are difficult to identify until at least 6 to 12 hours have elapsed following the onset of necrosis. ${ }^{3}$

The precursor of BNP and N-terminal pro - Brain Natriuretic Peptide (NT-proBNP) is a pre-pro hormone BNP, a 134 - amino-acid peptide that is synthesized in the myocytes and cleaved into the prohormone BNP (proBNP) which consist from 108 amino acids, a precursor molecule stored in secretory granules in myocyte. ${ }^{4}$ The prohormone is released during homodynamic stress from the left and right cardiac ventricle in response to ventricular volume expansion and pressure overload. Recent data suggest that left ventricular end diastolic wall stress and wall stiffness may be the predominate triggers of BNP release. ${ }^{\mathbf{5}}$ Upon release, prohormone BNP 108 is cleaved in the circulation by the serine proteinase known as furin into two polypeptides: the inactive NT- proBNP, 76 amino acids in length, and BNP, a bioactive peptide 32 amino acids in length. ${ }^{6}$

\section{Study Patients}

\section{Patients and Methods}

This prospective study was composed of 70 consecutive patients with ACS who were seen between April 2015 and April 2017 and 20 healthy subjects as control group. The present study was conducted at the Department of Bio Chemistry, College of Medicine, University of Baghdad and Baghdad Teaching Hospital. Patients diagnosed with ACS were selected according to the international consensus definition. ${ }^{7}$ The Ethics Committee of the Heart Institute (InCor) approved this study, and written informed consent was obtained from all participants. the patients were divided into five groups according to type of ACS :

I-Extensive MI: this group included 26 patients, 18 Male and 8 Female.

П-Anteroseptal MI: this group included 10 patients, 9 Male and 1

Female.

III-Anterior MI: this group included 2 patients, 1 Male and 1 Female.

IV-Inferior MI: this group included 18 patients, 15 Male and 3 Female.

V-Unstable angina: this group included 14 patients, 9 Male and 5 Female.

\section{Laboratory Analyses}

Routine blood samples were collected at admission with fasting status, and the troponin I, C-reactive protien, and NT-PRO BNP levels were measured. For the NT-PRO BNP determination, a specific kit for the ELIZA Centaur analyzer was used, which had a detection limit of $2 \mathrm{pg} / \mathrm{mL}$ and range from 2 to $5000 \mathrm{pg} / \mathrm{mL}$. The intra- and interassay coefficients of variation ranged from 2.1 to $4.7 \%$ for concentrations between 29 and $1700 \mathrm{pg} / \mathrm{mL}$. For this study, a level of $110 \mathrm{pg} / \mathrm{mL}$ was considered abnormal based on the manufacturer's recommended cut-off value. ${ }^{\mathbf{8 9}}$ Glucose level was measured by using enzymatic colorimetric method.

\section{Electrocardiography}

ECGs was performed upon hospital admission and was repeated soon after medication was started.. Each tracing was evaluated by two cardiologists for the presence or absence of acute ischemic changes based on the presence or absence of (1) ST-segment depression $0.5 \mathrm{~mm}$ and ST segment elevation of $\geq 0.1 \mathrm{mV}$ in 1 of the limb leads or $\geq 0.2 \mathrm{mV}$ in $\geq 2$ of the chest leads (2) $\mathrm{T}$ wave changes. Patients with acute ischemic changes were categorized according to the location of the acute ischemic region into groups with anterior (V1, V2, V3, V4), inferior (DII, DIII, aVF), or lateral wall (V5, V6, DI, aVL) involvement.

\section{Echocardiography}

Images were acquired using a transthoracic approach with M-mode, 2-dimensional, spectral Doppler (pulsed and continued) and color flow mapping. The LVEF was calculated using Simpson's method.

\section{Results}

This study included 70 patients with mean \pm SD of age was $(58.77 \pm 11.45)$ years ranged from $(25-84)$ years divided into two groups: Male group included 52(74.3\%) patients, and female group included $18(25.7 \%)$ patients. The patients with ACS were found to have significantly higher mean ( \pm SEM) value of serum NTPROBNP concentrations $(\mathrm{p}=0.0144)$ as compared with mean $( \pm \mathrm{SEM})$ value of serum control group, and significantly higher mean $( \pm \mathrm{SEM})$ value of serum hs-CRP concentrations $(\mathrm{p}=0.002)$ as compared with mean $( \pm$ SEM) value of serum control group. The mean $( \pm$ SEM) value of serum hs-troponin I concentrations did not differ significantly $(\mathrm{p}=0.372)$ as compared with mean $( \pm \mathrm{SEM})$ value of serum control group. 
Table 1: Demographic and base line clinical variables for Acs studied patients and control.

Variables

$\operatorname{Age}(\operatorname{mean} \pm$ SD)

Sex

Male

Femal

Risk factor

Diabetes

Hypertension

Dyslipidemia

Smoking

Obesity

(mean \pm SD)

NT-PROBNP level(ng/L)

TnI: Troponin I (ng/L)

CRP:C-Reactive protein $(\mathrm{mg} / \mathrm{L})$
Case

58.7

$52(74.3 \%)$

9(47.4\%)

$35(50 \%)$

$44(62.9 \%)$

9(12.9\%)

$29(41.4 \%)$

$22(31.4 \%)$

$204.95 \pm 21.42$

$8.20 \pm 0.87$

$12.83 \pm 0.97$
Contro

$$
33.4
$$

$10(50 \%)$

$10(50 \%)$

oo $\%$

$00 \%$

$00 \%$

$00 \%$

$00 \%$

$107.79 \pm 4.23$

$7.74 \pm 0.48$

$0.316 \pm 0.143$

Table (2) show the validity parameters in differentiating between cases with ACS and controls. The concentrations at optimal cut-off level of NT-PROBNP $=145.61(\mathrm{ng} / \mathrm{L})$, showed a sensitivity and specificity of $40 \%$ and $100 \%$ in ACS. The concentrations at optimal cut-off level of hs-Tnl=12.02 (ng/L), showed a sensitivity and specificity of $10 \%$ and $100 \%$ in ACS. The concentrations at optimal cut-off level of hs-CRP=1.576 (mg/L), showed a sensitivity and specificity of $89 \%$ and $95 \%$ in ACS.

Table (2) The validity parameters in differentiating between cases with ACS and controls.

\begin{tabular}{|c|c|c|c|c|c|c|c|c|c|}
\hline parameter & $\begin{array}{l}\text { Positive } \\
\text { if } \geq \text { cuth } \\
\text { off value }\end{array}$ & 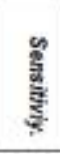 & 言咅 & 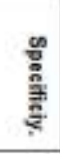 & 爱言 & PPV & & NPV & 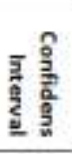 \\
\hline $\begin{array}{l}\text { NTPROBNP } \\
(\mathrm{ng} / \mathrm{l})\end{array}$ & 145.61 & 0.40 & $\begin{array}{l}0.29 \\
0.52\end{array}$ & 1.0 & $\begin{array}{l}0.79 ; \\
1.00\end{array}$ & 1.0 & $\begin{array}{l}0.85: \\
1.00\end{array}$ & 0.31 & $\begin{array}{l}0.20 ; \\
0.44\end{array}$ \\
\hline \begin{tabular}{|l|} 
hs - \\
Tnl(ng/L)
\end{tabular} & 12.02 & 0.10 & $\begin{array}{l}0.04 \\
0.20\end{array}$ & 1.00 & $\begin{array}{l}0.79 \\
1.00\end{array}$ & 1.0 & $\begin{array}{l}0.56 ; \\
0.99\end{array}$ & 0.23 & $\begin{array}{l}0.15: \\
0.34\end{array}$ \\
\hline $\begin{array}{l}\text { hs- } \\
\text { CRP(mg/L) }\end{array}$ & 1.576 & 0.89 & $\begin{array}{l}0.78: \\
0.95\end{array}$ & 0.95 & $\begin{array}{l}0.72 ; \\
1.00\end{array}$ & 0.98 & $\begin{array}{l}0.90 ; \\
1.00\end{array}$ & 0.69 & $\begin{array}{l}0.48 ; \\
0.85\end{array}$ \\
\hline
\end{tabular}

PPV=Posetive Predictive value

NPV=Negative Predictive value

From the ROC (receiver operator characteristics) curve (figure 1) the area of NT-PROBNP, hs-CRPand hs-TnI was $0.640,0.982,0.293$ respectivly, this curve shows the relation between sensitivity (rate of true positive) and rate of false negative (1-specificity) for serum NT-PROBNP, hs-CRP and hs-TnI in differentiating between patients with ACS and healthy control.

\section{ROC Curve}

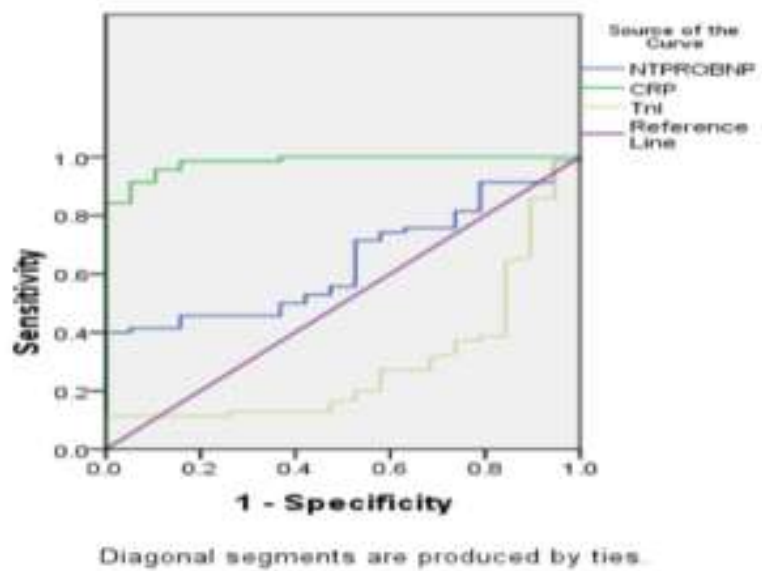

Figure 1 :Receiver operating characteristic curve (ROC) showing the performance ofNT-PROBNP, hs-CRP and hs-Tnl in ACS as if they are used as screening tests. 
The table (3) shows distribution of biochemical markers \& echocardiographic parameters according to types of Acute Coronary Syndrome. There was significant difference in mean $( \pm$ SEM) value of NT-PROBNP concentrations among the five groups, $(\mathrm{P}$-value $=0.0255)$.

The mean $( \pm$ SEM) values of serum NT-PROBNP concentrations was significantly increased in Extensive MI group than Anteroseptal MI ( P-value=0.0219). The mean ( \pm SEM) values of serum NTPROBNP concentrations was significantly higher in Inferior MI group than Extensive MI group( Pvalue $=0.0377)$. The mean $( \pm$ SEM $)$ values of serum NT-PROBNP concentrations was non significantly higher in Unstable angina group than Extensive MI group ( $\mathrm{P}$-value $=0.2682$ ). The mean $( \pm \mathrm{SEM})$ values of serum NTPROBNP concentrations was non significantly higher in Anterior MI group than Anteroseptal MI group ( Pvalue $=0.271)$. The mean $( \pm$ SEM) values of serum NT-PROBNP concentrations was significantly higher in Inferior MI group than Antero septal MI group ( $\mathrm{P}$-value=0.0372). The mean $( \pm \mathrm{SEM})$ values of serum NTPROBNP concentrations was significantly higher in Unstable angina group than Antero septal MI group ( Pvalue=0.0217). The mean $( \pm$ SEM $)$ values of serum NT-PROBNP concentrations was significantly higher in Inferior MI group than Anterior MI group ( $\mathrm{P}$-value=0.0467).

The mean ( \pm SEM) values of serum NT-PROBNP concentrations was non significantly higher in Unstable angina group than Anterior MI group ( $\mathrm{P}$-value=0.478). The mean ( \pm SEM) values of serum NTPROBNP concentrations was non significantly higher in Inferior MI group than Unstable angina group ( Pvalue $=0.461)$. There was non significant difference in mean $( \pm$ SEM $)$ value of serum hs-troponin I concentrations among the five groups, $(\mathrm{P}$-value $=0.146)$. There was significant difference in mean $( \pm \mathrm{SEM})$ value of hs-CRP concentrations among the five groups, $(\mathrm{P}-\mathrm{value}=0.0478)$.

The mean $( \pm$ SEM) values of serum hs-CRP was significantly higher in Extensive MI group than Inferior MI group ( P-value=0.0417). The mean $( \pm$ SEM) values of serum hs-CRP concentrations was significantly higher in Extensive MI group than Unstable angina group(P-value=0.0148). The mean $( \pm \mathrm{SEM})$ values of serum hs-CRP concentrations was significantly higher in Antero septal MI group than Unstable angina group $(\mathrm{P}-\mathrm{value}=0.0263)$. The mean $( \pm \mathrm{SEM})$ values of serum hs-CRP concentrations was significantly higher in Anterior MI group than Unstable angina group $(\mathrm{P}-\mathrm{value}=0.0366)$.

The mean $( \pm \mathrm{SEM})$ values of serum hs-CRP concentrations was non significantly higher in Extensive MI group than Anteroseptal MI group (P-value=0.366). The mean $( \pm \mathrm{SEM})$ values of serum hs-CRP was non significantly higher in Extensive MI group than Anterior MI (P-value=0.702). The mean $( \pm \mathrm{SEM})$ values of serum hs-CRP was non significantly higher in Anterior MI group than Anteroseptal MI group (P-value $=0.481$ ). The mean $( \pm \mathrm{SEM})$ values of serum hs-CRP concentrations was non significantly higher in Antero septal MI group than Inferior MI group $(\mathrm{P}-\mathrm{value}=0.478)$. The mean $( \pm \mathrm{SEM})$ values of serum hs-CRP concentrations was non significantly higher in Anterior MI group than Inferior MI group $(\mathrm{P}$-value $=0.366)$. The mean $( \pm \mathrm{SEM})$ values of serum hs-CRP was non significantly higher in Inferior MI group than Unstable angina group (Pvalue $=0.219)$. There was non significant difference in the mean $( \pm$ SEM) values of echocardiographic parameters among the five groups of ACS patients,table(3).

Table(3) Distribution of biochemical markers \& echocardiographic parameter according to types of Acute Coronary Syndrome.

\begin{tabular}{|c|c|c|c|c|c|c|}
\hline \multirow[t]{2}{*}{ Parameters } & \multicolumn{5}{|c|}{ Types of ACS: Acute Coronary Syndrome } & \multirow[t]{2}{*}{ P-value } \\
\hline & $\begin{array}{l}\text { Extensive MI } \\
\text { No. }=26\end{array}$ & $\begin{array}{l}\text { Antero- } \\
\text { septal MI } \\
\text { No. }=10\end{array}$ & $\begin{array}{l}\text { Anterior MI } \\
\text { No. }=2\end{array}$ & $\begin{array}{l}\text { Inferior MI } \\
\text { No. }=18\end{array}$ & $\begin{array}{l}\begin{array}{l}\text { Unstable } \\
\text { angina }\end{array} \\
\text { No. }=14\end{array}$ & \\
\hline NT-PROBNP(ng/L) & $199.67 \pm 15.47$ & $142.41 \pm 19.06$ & $195.37 \pm 22.53$ & $\begin{array}{ll}277.63 & \pm \\
26.42 & \end{array}$ & $229.08 \pm 22.61$ & $0.0255 *$ \\
\hline hs-TnI:Troponin I(ng/L) & $8.12 \pm 0.48$ & $5.39 \pm 0.71$ & $6.31 \pm 0.59$ & $8.60 \pm 0.62$ & $9.85 \pm 1.04$ & $0.146 \mathrm{NS}$ \\
\hline $\begin{array}{l}\text { hs-CRP: } \\
\text { C-reactive Protein(mg/L) }\end{array}$ & $15.56 \pm 0.84$ & $13.45 \pm 0.72$ & $14.66 \pm 0.92$ & $11.97 \pm 0.73$ & $7.12 \pm 0.12$ & $0.0478 *$ \\
\hline $\begin{array}{l}\text { LAD:Left atrium diameter } \\
\text { (cm) }\end{array}$ & $3.77 \pm 0.45$ & $3.39 \pm 0.51$ & $4.23 \pm 0.39$ & $3.46 \pm 0.61$ & $3.56 \pm 0.34$ & $0.492 \mathrm{NS}$ \\
\hline E/e & $10.68 \pm 0.79$ & $9.21 \pm 1.14$ & $9.52 \pm 0.95$ & $8.47 \pm 0.85$ & $8.47 \pm 0.74$ & $0.369 \mathrm{NS}$ \\
\hline $\begin{array}{l}\text { IVRT:Isovolumic } \\
\text { relaxation } \\
\text { time(ms) }\end{array}$ & $85.50 \pm 7.54$ & $89.00 \pm 12.68$ & $82.67 \pm 9.55$ & $93.71 \pm 9.02$ & $87.46 \pm 8.25$ & $0.853 \mathrm{NS}$ \\
\hline DT:Deceleration time(ms) & $178.54 \pm 15.83$ & $220.60 \pm 24.69$ & $182.00 \pm 19.71$ & $\begin{array}{l}192.67 \\
22.04\end{array}$ & $208.77 \pm 31.63$ & $0.262 \mathrm{NS}$ \\
\hline EF\%:Ejection fraction & $46.46 \pm 3.92$ & $50.80 \pm 6.41$ & $51.00 \pm 4.39$ & $54.72 \pm 4.82$ & $49.23 \pm 5.01$ & $0.720 \mathrm{NS}$ \\
\hline
\end{tabular}


ANOVA and t-test reveld that there was significant difference in mean $( \pm$ SEM) value of serum NT-PROBNP concentrations between Extensive MI group and Anteroseptal MI ( $\mathrm{P}$-value=0.0219 groups), Inferior MI group $(\mathrm{P}$-value $=0.0377)$. Antero septal $\mathrm{MI}$ and Inferior MI, Unstable angina(P-value $=0.0372,0.0217)$. Also Anterior $\mathrm{MI}$ and Inferior MI (P-value= 0.0467).

\section{Discussion}

The criteria used for acute myocardial infarction consisted of chest pain of $>20$ min duration combined with ST segment elevation of $\geq 0.1 \mathrm{mV}$ in 1 of the limb leads or $\geq 0.2 \mathrm{mV}$ in $\geq 2$ of the chest leads, or a rise in troponin. The localization was considered as anterior, An anterior wall myocardial infarction (AWMI or anterior STEMI) occurs when anterior myocardial tissue usually supplied by the left anterior descending coronary artery (LAD) suffers injury due to lack of blood supply. When an AWMI extends to the septal and lateral regions as well, the culprit lesion is usually more proximal in the LAD or even in the left main coronary artery. This large anterior myocardial infarction is termed an "extensive anterior". If the changes occurred in chest leads V2-V6, and inferior in leads II, III, and aVF.

The present study included 70 patients with mean \pm SD of age was $(58.77 \pm 11.45)$ years ranged from (25-84) years. Age is a strong risk factor for atherosclerotic diseases in western countries. The mortality and morbidity rates begin to increase after the age of 45 years in males and 55 years in females as reported by Walsh JM et al. (1995). ${ }^{\mathbf{1 0}}$ plasma NT-proBNP level, measured in acute coronary syndrome, independently might predict mortality rate, heart failure and degree of expansion of myocardial infarction. ${ }^{11}$ Plasma NT-proBNP reflects not only the size of the myocardial necrosis but also the extent of ischemic territory. Indeed, plasma NT-proBNP is increased in patients with acute coronary syndrome, even in the absence of necrosis. ${ }^{\mathbf{1 2}}$

The present study result showed there was significant differences in mean $( \pm \mathrm{SEM})$ value of serum NT-PROBNP concentrations $(\mathrm{P} \leq 0.05)$ among five groups of ACS, mean $( \pm$ SEM) value of NT-PROBNP concentrations in Inferior MI > Unstable angina > Extensive MI > Anterior MI > Anteroseptal MI, there were no previous studies in this section to rely on for comparison among five types of acute coronary syndrome, but there are studies which made comparison among several types of acute coronary syndrome. Elevated BNP levels were shown to be indicative of involvement of the anterior descending artery. ${ }^{\mathbf{1 3}}$ Roge rio Bicudo Ramos et al. ${ }^{14}$ considered exclusive ability of the BNP levels to predict the location in the LV anterior wall in a population sample including patients with a high frequency of previous heart failure may be explained by its correlation with the ischemic myocardial area at risk in this cohort.

Maria Dorobantu et al. ${ }^{\mathbf{1 5}}$ demonstrated that the early BNP measurement provides important information regarding systolic LV dysfunction in STEMI with anterior location patients undergoing revascularization, they provides support for the use of BNP as a screening tool for systolic LV dysfunction in anterior AMI patients at a threshold of $90 \mathrm{pg} / \mathrm{ml}$. Elevated BNP after AMI identifies patients at risk of adverse left ventricular remodeling, chronic left ventricular dysfunction and congestive heart failure. ${ }^{\mathbf{1 6}}$

A. Fazlinezhad et. al reported that the site of infarction was anterior in $41.9 \%$ (mean BNP level $=4208.92 \pm 508.067 \mathrm{pg} / \mathrm{ml})$, inferior-posterior in $25.8 \%$ (4436.63 $\pm 688 \mathrm{pg} / \mathrm{ml})$, isolated inferior wall infarction in $19.4 \%(598.83 \pm 309.867 \mathrm{pg} / \mathrm{ml})$, inferior right ventricle in $12.9 \%(1462 \pm 141.297 \mathrm{pg} / \mathrm{ml})$ of the patients. The highest level of BNP was in posterior-inferior MI and the lowest one in isolated inferior wall MI. There was no significant relationship between BNP levels and infarction location $(P=0.13) .{ }^{17}$

\section{Conclusion}

Analysis of NT-proBNP help emergency physicians in managing patients with a variety of conditions. They are primarily helpful in difficult-to-diagnose causes of dyspnea. They are a strong tool in the ED to differentiate ACS from its various mimics and are also helpful in monitoring of ACS therapy. NT-proBNP are powerful prognostic tools in ACS and various other clinical settings. Patient's factors like age, sex, obesity, , and renal dysfunction might alter the plasma concentration of BNP and NT-proBNP; so in the presence of these conditions, values of natriuretic peptides should be interpreted cautiously. Evidence suggests that BNP and NTproBNP may also assist in deciding optimal treatment of various other clinical conditions. Despite extensive utility of NT-proBNP in the ED in ACS, further studies are needed to consolidate the diagnostic and prognostic significance of these peptides in various types of ACS.

\section{References}

[1]. Watanabe I, Tani S, Washio T, et al. Relationship between the plasma levels of brain natriuretic peptide and left ventricular ejection fraction in asymptomatic patients with previous myocardial infarction. Int Heart J. 2005;46:1007-14.

[2]. Talwar S, Squire IB, Downie PF, et al. Profile of plasma N-terminal proBNP following acute myocardial infarction; correlation with left ventricular systolic dysfunction. Eur Heart J. 2000;21:1514-21.

[3]. Štambuk K, Bulj N, Trbušić M, Krčmar T, Lukinac L. B-type Natriuretic Peptide as Predictor of Heart Failure in Patients with Acute ST Elevation Myocardial Infarction, Single-vessel Disease, and Complete Revascularization: Follow-up Study, newCroat Med J. October 2009;50(5): 449-54. 
[4]. Tang WH, Girod JP, Lee MJ, et al. : Plasma BNP levels in ambulatory patients with established chronic symptomatic systolic heart failure. Circulation. 2003;108:2964-2966.

[5]. Iwanaga Y, Nishi I, Furuichi S. : B-type natiruretic peptide strongly reflects diastolic wall stress in patients with chronic heart failure. Comparison between systolic and diastolic heart failure. J AM Coll Cardiol . 2006;47:742-8.

[6]. Tang WH, Francis GS, Morrow DA, et al. : National Academy of clinical biochemistry laboratory medicine practice guidelines: utilization of cardiac biomarker testing in heart failure. Circulation 2007;116:99-109.

[7]. Alpert JS, Thygesen K, Antman E, Bassand JP. Myocardial infarction redefined--a consensus document of The Joint European Society of Cardiology/American College of Cardiology Committee for the redefinition of myocardial infarction. J Am Coll Cardiol 2000;36:959-969, doi: 8-1016/S0735-1097(00)00804-4

[8]. Bassan R, Potsch A, Maisel A, Tura B, Villacorta H, Nogueira MV, Campos A, Gamarski R, Masetto AC, Moutinho MA. B-type natriuretic peptide: a novel early blood marker of acute myocardial infarction in patients with chest pain and no ST-segment elevation. Eur Heart J 2005;26:234-240, doi: 10.1093/eurheartj/ehi033.

[9]. National Committee for Clinical Laboratory Standards. How to define, determine, and utilize reference intervals in the clinical laboratory; approved guideline. NCCLS Document C28-A. Wayne (PA): NCCLS; June1995.

[10]. Walsh JM, and Grady D. : Treatment of hyperlipidemia in women. JAMA ,1995;274:1152-1158

[11]. Kistorp C, Raymond I, Pedersen F, et al. : N-terminal pro-brain natriuretic peptide, C-reactive protein, and urinary albumin levels as predictors of mortality and cardiovascular events in older adults. JAMA. 2005;293(13):1609-1616.

[12]. S Štambuk K, Bulj N, Trbušić M, et al. : B-type Natriuretic Peptide as Predictor of Heart Failure in Patients with Acute ST Elevation Myocardial Infarction, Single-vessel Disease, and Complete Revascularization: Follow-up Study, newCroat Med J. October 2009;50(5): 449-54.

[13]. Palazzuoli A, Gennari L, Calabria P, et al. : Relation of plasma brain natriuretic peptide levels in non-ST-elevation coronary disease and preserved systolic function to number of narrowed coronary arteries. Am J Cardiol 2005;96:1705-1710. Epub 2005 Nov 2., doi: 10.1016/j.amjcard.2005.07.094

[14]. Rogério Bicudo Ramos, Ce' lia M Strunz, Solange Desire'e Avakian, et al. : B-type natriuretic peptide as a predictor of anterior wall location in patients with non-ST-elevation myocardial infarction. CLINICS 2011;66(3):437-441.

[15]. Maria Dorobantu, Ana-Gabriela Fruntelata, Alexandru Scafa-Udriste, Oana-Florentina Tautu : B-Type Natriuretic Peptide (BNP) and Left Ventricular (LV) Function in Patients with ST-Segment Elevation Myocardial Infarction(STEMI). Maedica A Journal of Clinical Medicine, Volume 5 No.4 2010.

[16]. de Lamos JA, McGuire DK, Drazner MH. - B-type natriuretic peptide in cardiovascular disease. Lancet. 2003; 362: 316-322. 